\title{
The impact of the COVID-19 pandemic on socio-economic and sustainability
}

\author{
Xueli Wei ${ }^{1,2} \cdot{\text { Lijing } \mathrm{Li}^{1} \cdot \text { Fan Zhang }}^{1}$ \\ Received: 5 April 2021 / Accepted: 15 June 2021 / Published online: 15 July 2021 \\ (C) The Author(s) 2021
}

\section{Pumping elephant}

The COVID-19 pandemic has adversely affected the lives of people around the world in millions of ways . Due to this severe epidemic, all countries in the world have been affected by all aspects, mainly economic. It is widely discussed that the COVID-19 outbreak has affected the world economy. When considering this dimension, this study aims to examine the impact of the COVID-19 pandemic on the world economy, socio-economics, and sustainability. In addition, the research focuses on multiple aspects of social well-being during the pandemic, such as employment, poverty, the status of women, food security, and global trade. To this end, the study used time series and cross-sectional analysis of the data. The second-hand data used in this study comes from the websites of major international organizations. From the analysis of secondary data, the conclusion of this article is that the impact of the pandemic is huge. The main finding of the thesis is that the social economy is affected by the pandemic, causing huge losses in terms of economic well-being and social capital.

Key words coronavirus disease $\cdot$ Pandemic $\cdot$ poor $\cdot$ Employment $\cdot$ food safety $\cdot$ Social economy $\cdot$ Sustainability

\section{Introduction}

As the new coronavirus rages and affects people on all continents exponentially, the entire world is in a state of panic and pain. It is difficult to point out that a country has not been affected by this deadly virus. Few single epidemics have a serious and lasting impact on the world economy, global health, and human life as a whole.

The Great Influenza Pandemic broke out from 1918 to 1920 , which was considered as the fourth-largest macroeconomic shock that affected the economy adversely after the two World Wars and The Great Depression (Barro and Weng 2020). It has been found using geographic mortality variation that during the pandemic of 1918, the areas of the USA which were exposed to the pandemic experienced a persistent and steep decline in the economic activities (Sergio et al. 2020;

Editor in charge: Lotfi Aleya

Fan Zhang

fanzhang.research@gmail.com

1 Harbin Medical University, Daqing 163319, Heilongjiang, China

2 University of Chinese Academy of Social Sciences, Beijing 100102, China
Sundararaj et al. (2018) Rejeesh 2019; Sundararaj et al. 2018; Vinu 2019; Sundararaj 2016; Tiwari et al. 2021; Sundararaj and Rejeesh 2021).

The world is expected to face a severe recession even if the spread of the virus is controlled. The effects of this pandemic will haunt mankind for several years in terms of employment, health care systems, income, and human development.

Even though not many people are dying due to the infection of the deadly virus, the number of people that are being affected in a region are causing health systems to break down resulting in more deaths. To deal with the COVID-19 outbreak, strong prevention measures such as strengthening the immune system and improving the proper sanitary conditions which are often lacking in most middle- and low-income countries should be stressed. Thus, the people at the lowest rung of the economy are more vulnerable to the virus. Developing countries were already facing shortage of funds to undertake developmental and infrastructure projects. Due to the pandemic, more funds are now being allotted to emergency health care systems making these projects all the more difficult to undertake. Generally, 3-4\% of the gross domestic product of a country is spent on costs related to illnesses resulting from high fatality scenarios, especially during the pandemic times. It is found that the percentage is higher for extreme pandemics (Smith et al. 2009). 
To contain the spread of the virus, most countries have implemented lockdown measures. However, lockdown measures have severely affected the economy and a large number of people. Several people lost their jobs while several others are undergoing pay-cuts, which is affecting the income of their respective families. Essential services such as logistics have been halted due to the strict measures implemented in the pandemic times. Even education is being compromised, and, as a result, schools, colleges, and universities are closed. If widespread behavioral changes take place due to the lockdown and large-scale absence from work is persistent, the economic damage will be far greater than the health benefits (Smith et al. 2009).

Economic conditions across the world are also in a state of destitution. Global production has suffered, along with various service industries primarily including tourism and airlines, due to strict lockdown measures. Since the future is uncertain, investment rates will remain low. However, private investments will be extremely important, especially in developing countries because governments are already running out of funds, as they are dealing with the pandemic and will thus be unable to take up investment projects.

Social and humanitarian aspects of the pandemic are also causing stress and anxiety in the public. Women, children, and the elderly are highly exposed to the virus, as they are among the weaker sections of the society and thus are more vulnerable. The lockdown has also compromised the safety of women, and increased cases of domestic violence have been reported. Refugees, informal sector workers, and the unemployed often find it hard to access government-provided health care schemes and other benefits. It is noted that the above listed people were the most affected by the pandemic.

Therefore, the COVID-19 situation has left its mark on every part of our society and has changed our way of life forever.

\section{Materials and methods}

\section{Data description}

\section{a. Quarterly GDP}

Gross domestic product (GDP) is the standard measure of the value-added created through the production of goods and services in a country. As such, it also measures the income earned from the production or the total amount spent on final goods and services (fewer imports). While GDP is the most important indicator to capture economic activity, it falls short of providing a suitable measure of people's material wellbeing for which alternative indicators may be more appropriate. This indicator is based on real GDP (also called GDP at constant prices or GDP in volume), i.e., the developments over time are adjusted for price changes. The numbers are also adjusted based on seasonal influences. The indicator is available in different measures: percentage change from the previous quarter, percentage change from the same quarter of the previous year, and volume index. All OECD countries compile their data according to the 2008 System of National Accounts (SNA).

\section{b. Unemployment rate}

Unemployment rate forecast is defined as the projected value for the number of unemployed people as a percentage of the labor force, where the latter consists of the unemployed plus those in paid or self-employment. Unemployed people are those who report that they are without work, that they are available for work, and that they have taken active steps to find work in the last 4 weeks. When unemployment is high, some people get discouraged and stop looking for work; they are then excluded from the labor force.

\section{c. Global activity indicator}

Air pollution is the change in $\mathrm{NO} 2$ emissions from January 1 to May 28 in 2019 and 2020.

Retail and recreation mobility is the change in percent from May 21, 2020, from baseline, which is the median value for the corresponding day of the week during the 5 -week period January 3-February 6, 2020, based on data from Google.

Flight cancellations show the cancellations relative to total planned flights based on comparing currently operating flights in 2020 with flights that were operating 52 weeks ago in 2019 as of May 27, 2020.

OpenTable reservations show the change in seated dinners at restaurants on the OpenTable network on May 27 in 2019 and 2020.

\section{Method}

This study employs out both time series and cross-sectional analysis of data. The data used in this study are secondary and have been sourced from the websites of major international organizations.

\section{Results}

Let us look at the effects of the COVID-19 pandemic on various aspects of sustainability and social economy.

\section{Poverty}

Global poverty is defined as the share of the population of the world earning less than 1.9 dollars a day. 
The World Bank estimates that the COVID-19 pandemic will push about 40 to 60 million people into extreme poverty (Gerzon Mahler et al. 2020). The Global Economic Prospects (World Bank 2020) forecast two scenarios of the effect that the pandemic might have on poverty. One in which the outbreak remains at the current expected level and economic activities recover during the latter part of this year and another in which the outbreak continues for a longer period of time to force the introduction and furthering of lockdown measures. The former will contract global growth by about $5 \%$ in 2020 while the latter will lead to a growth contraction of $8 \%$.

Figure 1 shows the quarterly GDP for the first quarter of 2020 for 41 countries based on the availability of data (see Table 1 in the Appendix for tabulated values) (OECD 2020a).

Figure 2 shows the aggregate OECD GDP for a period of 21 years (2000-2020) (see Table 2 in the Appendix for tabulated values) (OECD 2020a).

If the outbreak persists, vulnerable households will reduce consumption by a great margin and firms in critical conditions will exit markets. Increased financial stress will be experienced by middle- and low-income countries.

For the first time, global poverty is forecasted to increase, since 1998. It is forecasted that it will increase to $8.6 \%$ in 2020 from $8.2 \%$ in 2019 . In absolute terms, the number will rise to 655 million people from 632 million (Sumner et al. 2020).

Global growth is also forecasted to fall by the World Bank.

Figure 3 shows the aggregate growth rates calculated using GDP weights at 2010 prices and market exchange rates for 12 years (2010-2021) (data for 2019 are estimates) (see Table 3 in the Appendix for tabulated values) (Global Economic Prospects 2020).
OECD Economic Outlook projects the global GDP to fall in 2020 by more than $7 \%$. In OECD countries, the situation is worse. OECD GDP is forecasted to fall by more than $9 \%$ in 2020. Under the single hit scenario, global GDP is anticipated to drop by $6 \%$ and OECD GDP by more than $7 \%$ in 2020 . In the second quarter of 2020, world output is forecasted to be more than $12 \%$ lower than in the previous quarter (OECD 2020b).

\section{Unemployment}

Employment is a primary aspect of sustainable development in any society. It is essential for people to have respectable jobs for them to enjoy the growth of the economy (Osmani 2003; Monia and Rim 2018; Kabanda 2016; Messkoub 2018; Alauddin 2016; Padovan et al. 2019).

The coronavirus pandemic has exposed the world to the biggest decline in employment since the Second World War. Since all activities came to a halt due to the global pandemic, employment experienced a massive and halting blow. Most people working in the informal sector have a little or no savings at all. Due to the recent COVID-19 crisis, they lost almost $60 \%$ of their income (World Bank Predicts Sharpest Decline of Remittances in Recent History 2020).

Figure 4 shows the unemployment rate for the first quarter of 2020 for 31 countries based on the availability of data (see Table 4 in the Appendix for tabulated values) (OECD 2020b).

Figure 5 shows the aggregate unemployment rate in OECD countries for a period of 21 years (2000-2020) (see Table 5 in the Appendix for tabulated values) (OECD 2020c).

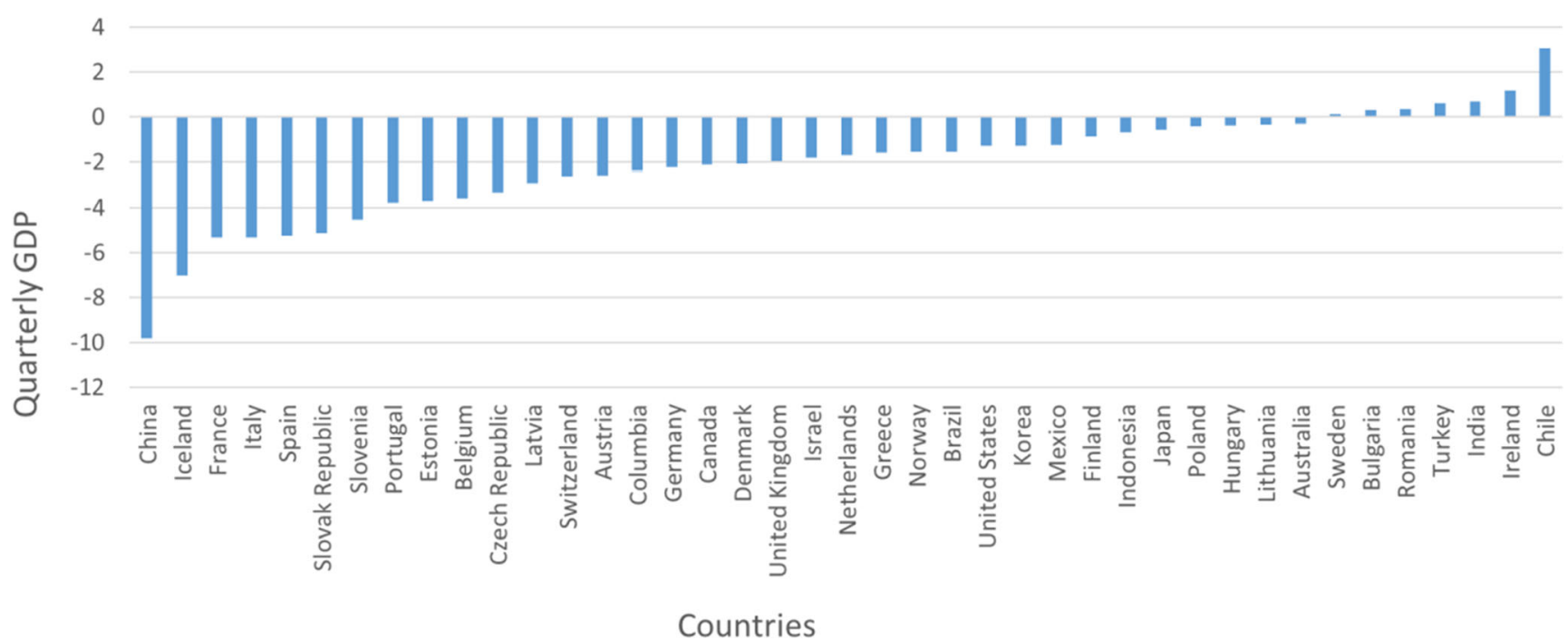

Fig. 1 Quarterly GDP for 2020 


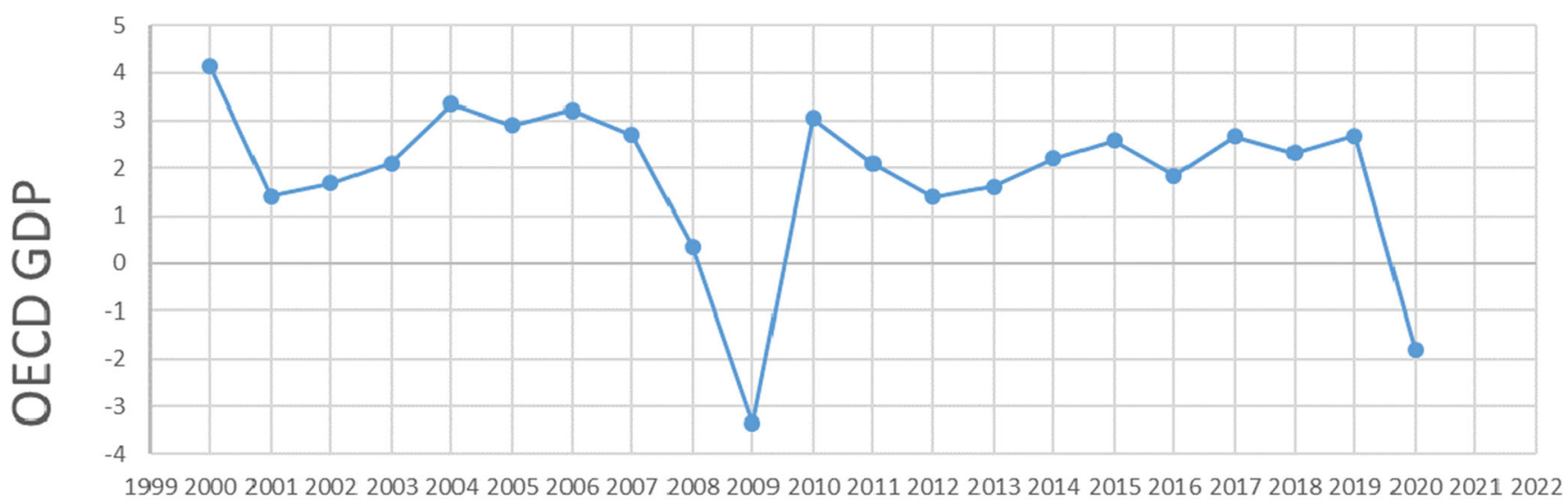

Year

Fig. 2 Aggregate OECD GDP

The lockdown has been in effect in several countries along with school and workplace closures, travel restrictions, and social distancing policies. By the beginning of April, almost $81 \%$ of the total workforce in the world experienced workplace closures. Even though these measures were necessary, they adversely affected firms and workers.

Figure 6 shows the percentage change in global activities indicators around the world, namely, air pollution retail and recreation mobility, flight cancellations, and OpenTable reservations (see Table 6 in the Appendix for tabulated values) (Global Economic Prospects 2020).

The ILO (International Labour Organization) has projected the global work hours around the world to decrease by $4.5 \%$ in the first quarter of 2020 and $10.5 \%$ in the second amounting to 305 million workers working $48 \mathrm{~h}$ a week. This outpaces the fall in employment during the Global Financial Crisis of 2008-09 (ILO 2020).

\section{The impact on women}

Seventy percent of the people working in the health care and social sector are women (United Nations 2020). Front-line health workers including nurses and midwives are mostly women. They also form a majority of the service staff in the health care sector like laundry, catering, and cleaning. Thus, they are more vulnerably exposed to the virus.

Women undertake thrice as much unpaid work as men. The situation is projected to get worse under the COVID19 pandemic because children will remain out of school, older persons will require attentive care, and the health service will collapse under severe conditions of the pandemic (UN Women Headquarters 2020).

Women generally live close to poverty and hold insecure jobs. They earn less and save less. The compounded economic

Fig. 3 Global growth rates

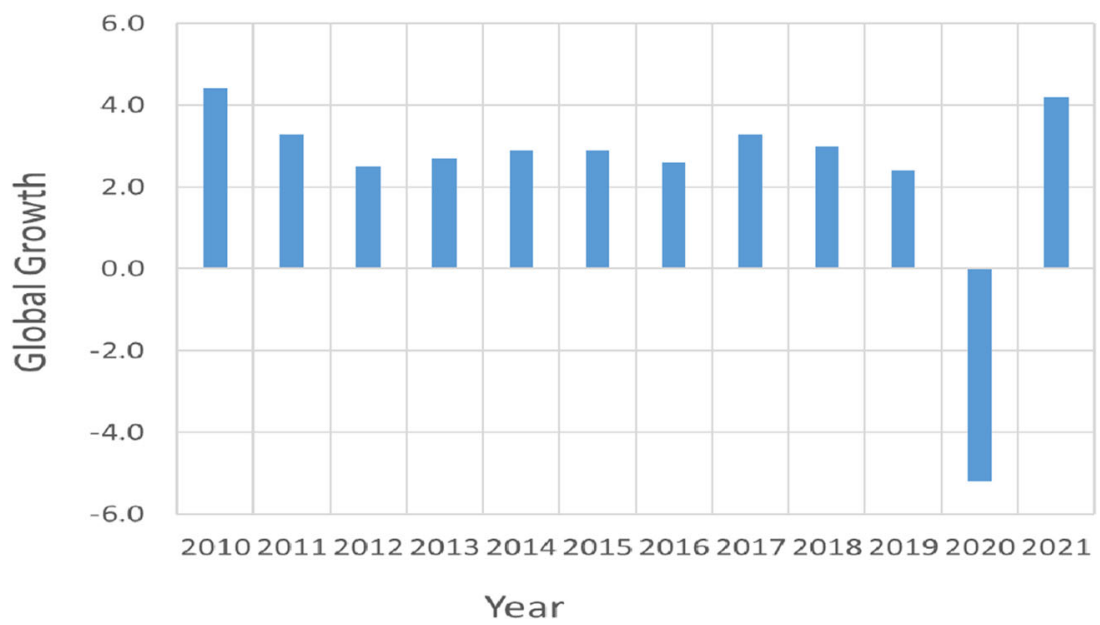




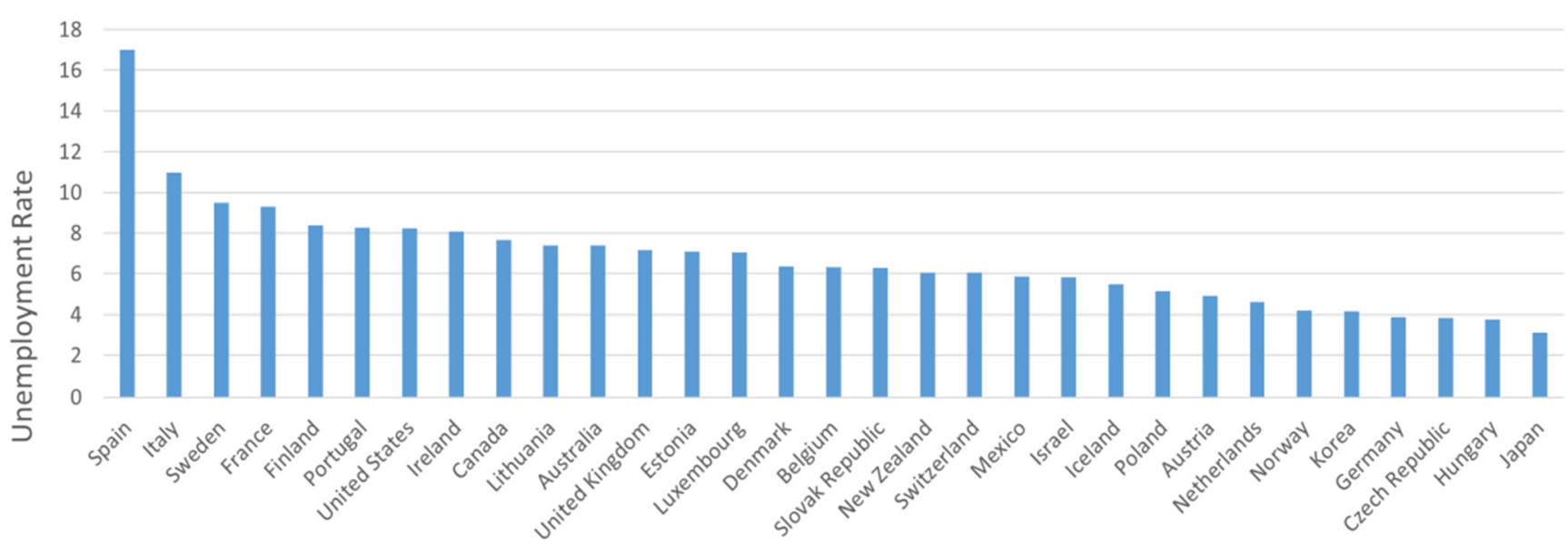

Countries

Fig. 4 Unemployment rate for countries

hardships resulting from the pandemic will thus have severe effects on women.

Gender-based violence is increasing exponentially with social isolation measures and restrictions in movement. Due to the lockdown effect, women are being forced to stay at home with their abusers. Also, services to offer assistance to the survivors are also being disrupted, in these pandemic times. Various countries around the world have reported an increase in the number of complaints related to domestic violence.

Women have unique health needs. However, they have lost access to quality health services, reproductive and maternal health care, and essential vaccines and medications. Gender stereotypes and restrictive social norms can also adversely affect the accessibility of health services to women.

\section{Global trade}

Because of the coronavirus pandemic, global trade is also experiencing a halting effect. It is estimated that within the first quarter of 2020 the volume of goods and services traded have suffered a fall of $3 \%$. This is because international travel has been restricted to contain the spread of the virus.

Demand has collapsed and supplies disrupted due to the cessation of international travel. International freight traffic in 2020 has been $30 \%$ lower than that of the previous year and international passenger traffic is $98 \%$ lower than the previous year.

Global export figures reached an all-time low in April 2020 and remained weak throughout May. Almost all the countries reported significant declines in trade values. Countries with relatively light containment measures are also suffering because of reduced external demand due to the pandemic.

UNCTAD nowcasts for global trade values in the first quarter of 2020 fell by $3 \%$ with respect to the previous quarter.

UNCTAD's Free Market Commodity Price Index (FMCPI) lost $1.2 \%$ of its value in January, $8.5 \%$ in February, and $20.4 \%$ in March. The FMCPI never fell by

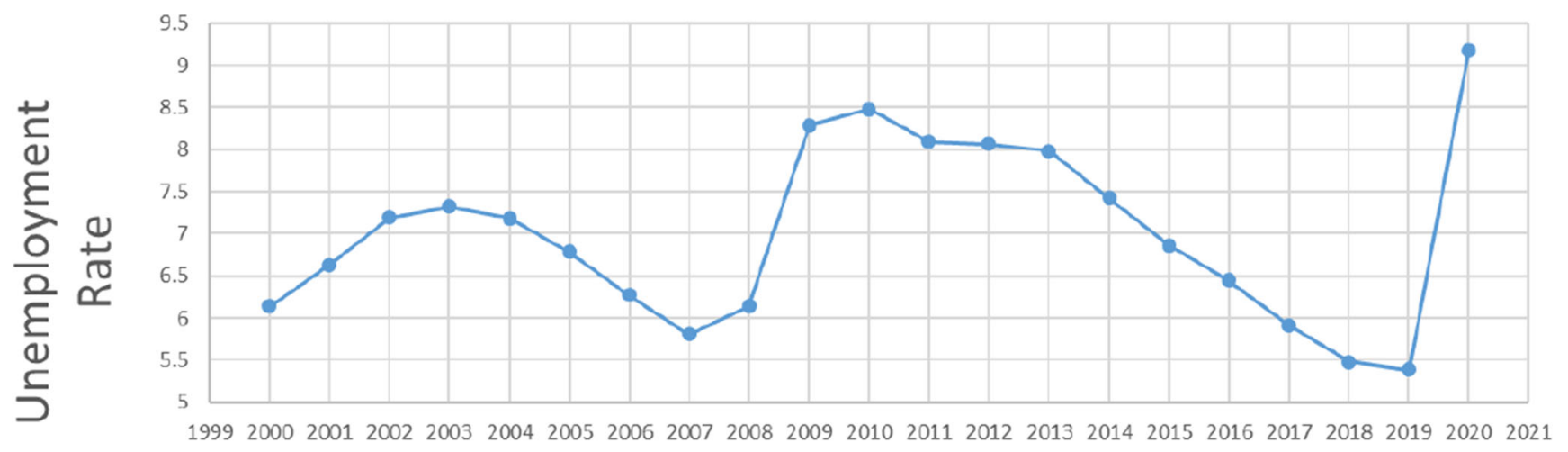

Fig. 5 OECD employment rates 
Fig. 6 Percentage change in global activity indicators

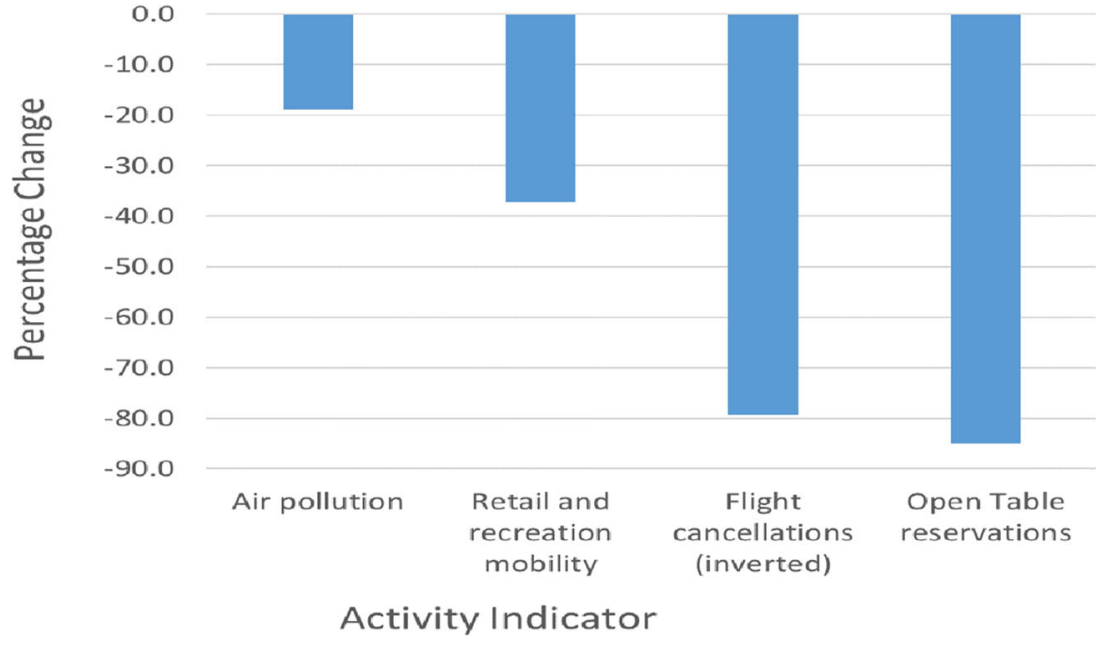

$20 \%$ in a single month before this. The closest case was during the time of the Global Financial Crisis of 2008-09 when it decreased by $18.6 \%$ (Back-of-the-Envelope Estimates of Next Quarter's Unemployment Rate 2020; COVID-19 and the St. Louis Fed 2020; Possible Fiscal Policies for Rare, Unanticipated, and Severe Viral Outbreaks 2020; COVID19 2020b; Inanc 2020; St-Denis 2020; Social Distancing and Contact-Intensive Occupations 2020; Adams-Prassl et al. 2020; Dasgupta and Murali 2020).

\section{Food security}

Under the present circumstances, the COVID-19 pandemic will double the number of people facing food crisis. UN forecasts that 265 million people in middle- and low-income countries are at the risk of facing acute food insecurity by the end of 2020. At present, 135 million people are acutely facing food security. They are spread across 55 countries across the world and are in urgent need of humanitarian food and nutrition assistance (UNWTO reports 2020; Unwto Reports 2020; COVID-19 2020a). They are the most vulnerable to the virus as they have little or no capacity to deal with the socio-economic and health aspects of the pandemic (FSIN. Global Report on Food Crises 2020; Global Report on Food Crises 2020; HLPE 2020).

Countries suffering from acute food security are facing a terrible trade-off between saving people from the virus and to have them die from hunger. The health systems in these countries are already overstretched with an acute shortage of equipment, doctors, and medicines. The poorer sections of the society often lack sufficient financial means to access health care and/or live in remote areas where these services never reach.

Food insecure people generally have higher rates of underlying health problems including malnutrition and other noncommunicable diseases which weaken the immune system and make these people more vulnerable to the coronavirus. Movement restrictions, strained health systems, and falling incomes have increased rates of malnutrition especially among lactating and pregnant women, children, and the elderly. Families which entirely rely on the feeding programs of schools to fill food gaps are also on the verge of facing acute food insecurity.

Even though the 2020 harvest has been good and the outlook for stable crops is quite promising, movement restrictions have disrupted the transport and processing of food crops along with other essential items. The availability of basic food items has also been compromised due to increased delivery times.

\section{Conclusion}

We can thus conclude that the most severe effects of the COVID-19 pandemic have been felt by the weaker sections of the society including women, the unemployed, and the poor. The virus has left its mark on all aspects of social well-being and has adversely affected the sustainability of the earth. Keeping in mind the huge amount of losses different sectors had to incur due to the pandemic, careful measures must be taken to fight the current pandemic and prevent future pandemics. The worst affected areas of the social economy include poverty, employment, women's well-being, and global trade. These are perhaps the most important aspects of human development and the pandemic undid most advancement made in these sectors.

Author contribution FZ agreed on the content of the study. XW and LL collected all the data for analysis. FZ agreed on the methodology. XW and LL completed the analysis based on agreed steps. Results and conclusions are discussed and written together. The author read and approved the final manuscript. 
Funding 1. Heilongjiang Provincial Education Science Planning Office's Special Project "Research on the Strategy for the Prevention and Control of the Epidemic in the Context of the COVID-19": Law Popularization Education Research on the Rule of Public Health Rule of Law in Institutions and Universities under Public Health Emergencies, No. GJE1320136

2. Key topics of Heilongjiang Education and Science "13th Five-Year Plan" in 2018: Practical Research on the Innovative Talent Training Mechanism of Heilongjiang Higher Medical Colleges, No. GBB1318076.

3. Heilongjiang Economic and Social Development Key Research Project Base: Research on the Legal Culture Construction of Traditional Chinese Medicine under the Context of the Traditional Chinese Medicine Law, No.: JD2017021.

4. Heilongjiang Provincial University Basic Scientific Research Business Fees Research Project: Research on the Effective Mechanism of the Integration of Outstanding Traditional Chinese Culture into the Ideological and Political Education of Universities, No. 2018-KYYWF0594

5. Heilongjiang Philosophy and Social Science Research Project: Research on Intellectual Property Protection of New Fields and New Business Innovation Achievements, No.: 19FXB039.

6. Heilongjiang Philosophy and Social Science Research Project: Research on Labor Employment and Social Security for People with Mental Disabilities in Heilongjiang Province, No. 17GLB026.

7. Daqing Campus of Harbin Medical University "In-School Scientific Research Fund": Legal Research on the Protection of Intellectual Property Rights in Traditional Chinese Medicine, No. DQXN201612.

8. Special topics for the study of the integration of outstanding traditional culture into ideological and political courses on the Daqing campus of Harbin Medical University: the integration of excellent traditional culture into ideological and political courses, the enhancement of cultural consciousness and self-confidence, number: DQCTWH201801.

9. Special Research Project on the Integration of Excellent Traditional Chinese Culture into Thought and Administration Courses on Daqing Campus of Harbin Medical University: Research on the Effective Mechanism of the Integration of Chinese Excellent Traditional Culture into College Thought and Political Science Courses, No. DQCTWH201802.

10. Sichuan Provincial Philosophy and Social Sciences Key Research Base Sichuan Medical and Health Law Research Center 2016 Project: Research on Labor Rights Protection for People with Mental Disabilities in Northeast China, No. YF16-Y02.

11 Key project of Daqing philosophy and social science planning research: research on the construction of healthy Daqing, number: DSGB2019035.

Data availability The datasets used and/or analyzed during the present study are available from the corresponding author on reasonable request.

\section{Declarations}

Human and animal rights

This article does not contain any studies with human or animal subjects performed by any of the authors.

Informed consent

Informed consent does not apply as this was a retrospective review with no identifying patient information.

Consent for participate

Not applicable.

Consent for publication

Not applicable.

Conflict of interest

The authors declare no competing interests.

\section{Appendix}

Table 1 Quarterly GDP for 2020

\begin{tabular}{|c|c|}
\hline Country & GDP \\
\hline China & -9.8 \\
\hline Iceland & -7.01243 \\
\hline France & -5.3432 \\
\hline Italy & -5.30942 \\
\hline Spain & -5.23722 \\
\hline Slovak Republic & -5.15558 \\
\hline Slovenia & -4.53152 \\
\hline Portugal & -3.76245 \\
\hline Estonia & -3.69071 \\
\hline Belgium & -3.59499 \\
\hline Czech Republic & -3.33146 \\
\hline Latvia & -2.90032 \\
\hline Switzerland & -2.60701 \\
\hline Austria & -2.56337 \\
\hline Columbia & -2.38534 \\
\hline Germany & -2.2218 \\
\hline Canada & -2.10899 \\
\hline Denmark & -2.07292 \\
\hline UK & -1.97549 \\
\hline Israel & -1.83293 \\
\hline Netherlands & -1.71629 \\
\hline Greece & -1.59793 \\
\hline Norway & -1.5473 \\
\hline Brazil & -1.53942 \\
\hline USA & -1.28638 \\
\hline Korea & -1.2817 \\
\hline Mexico & -1.24098 \\
\hline Finland & -0.85926 \\
\hline Indonesia & -0.68672 \\
\hline Japan & -0.56517 \\
\hline Poland & -0.40394 \\
\hline Hungary & -0.39062 \\
\hline Lithuania & -0.34324 \\
\hline Australia & -0.30586 \\
\hline Sweden & 0.121829 \\
\hline Bulgaria & 0.288235 \\
\hline Romania & 0.314825 \\
\hline Turkey & 0.615463 \\
\hline India & 0.65894 \\
\hline Ireland & 1.166176 \\
\hline Chile & 3.034375 \\
\hline
\end{tabular}


Table 2 Aggregate OECD GDP

\begin{tabular}{ll}
\hline Year & OECD GDP \\
\hline 2000 & 4.120418 \\
2001 & 1.402737 \\
2002 & 1.678441 \\
2003 & 2.107335 \\
2004 & 3.340186 \\
2005 & 2.907985 \\
2006 & 3.206121 \\
2007 & 2.691061 \\
2008 & 0.359443 \\
2009 & -3.35533 \\
2010 & 3.050615 \\
2011 & 2.08932 \\
2012 & 1.384969 \\
2013 & 1.611147 \\
2014 & 2.207396 \\
2015 & 2.575601 \\
2016 & 1.841686 \\
2017 & 2.666721 \\
2018 & 2.31723 \\
2019 & 2.68 \\
2020 & -1.8 \\
\hline
\end{tabular}

Table 4 Unemployment rate for countries

\begin{tabular}{ll}
\hline Country & Unemployment rate \\
\hline Spain & 17.0 \\
Italy & 11.0 \\
Sweden & 9.5 \\
France & 9.3 \\
Finland & 8.4 \\
Portugal & 8.3 \\
USA & 8.2 \\
Ireland & 8.1 \\
Canada & 7.7 \\
Lithuania & 7.4 \\
Australia & 7.4 \\
UK & 7.2 \\
Estonia & 7.1 \\
Luxembourg & 7.1 \\
Denmark & 6.4 \\
Belgium & 6.3 \\
Slovak Republic & 6.3 \\
New Zealand & 6.0 \\
Switzerland & 6.0 \\
Mexico & 5.9 \\
Israel & 5.8 \\
Iceland & 5.5 \\
Poland & 5.1 \\
Austria & 4.9 \\
Netherlands & 4.6 \\
Norway & 4.2 \\
Korea & 4.1 \\
Germany & 3.9 \\
Czech Republic & 3.8 \\
Hungary & 3.8 \\
Japan & 3.1 \\
\hline & \\
\hline
\end{tabular}

Table 3 Global growth rates

\begin{tabular}{ll}
\hline Year & Global growth rate \\
\hline 2010 & 4.4 \\
2011 & 3.3 \\
2012 & 2.5 \\
2013 & 2.7 \\
2014 & 2.9 \\
2015 & 2.9 \\
2016 & 2.6 \\
2017 & 3.3 \\
2018 & 3.0 \\
2019 & 2.4 \\
2020 & -5.2 \\
2021 & 4.2 \\
\hline
\end{tabular}


Table 5 OECD

employment rates

\begin{tabular}{ll}
\hline Year & OECD employment rate \\
\hline 2000 & 6.144492 \\
2001 & 6.630343 \\
2002 & 7.191543 \\
2003 & 7.325176 \\
2004 & 7.184701 \\
2005 & 6.783474 \\
2006 & 6.274324 \\
2007 & 5.808896 \\
2008 & 6.139248 \\
2009 & 8.292264 \\
2010 & 8.477786 \\
2011 & 8.091829 \\
2012 & 8.065573 \\
2013 & 7.984239 \\
2014 & 7.427004 \\
2015 & 6.861839 \\
2016 & 6.447021 \\
2017 & 5.920082 \\
2018 & 5.478733 \\
2019 & 5.386595 \\
2020 & 9.181022 \\
\hline
\end{tabular}

Table 6 Percentage change in global activity indicators

\begin{tabular}{ll}
\hline Indicators & Percent change \\
\hline Air pollution & -19.0 \\
Retail and recreation mobility & -37.2 \\
Flight cancellations (inverted) & -79.4 \\
OpenTable reservations & -85.0 \\
\hline
\end{tabular}

Open Access This article is licensed under a Creative Commons Attribution 4.0 International License, which permits use, sharing, adaptation, distribution and reproduction in any medium or format, as long as you give appropriate credit to the original author(s) and the source, provide a link to the Creative Commons licence, and indicate if changes were made. The images or other third party material in this article are included in the article's Creative Commons licence, unless indicated otherwise in a credit line to the material. If material is not included in the article's Creative Commons licence and your intended use is not permitted by statutory regulation or exceeds the permitted use, you will need to obtain permission directly from the copyright holder. To view a copy of this licence, visit http://creativecommons.org/licenses/by/4.0/.

\section{References}

Adams-Prassl A, Boneva T, Golin M, Rauh C (2020) Inequality in the impact of the coronavirus shock: new survey evidence for the UK. CEPR Discuss Pap 14665:15

Alauddin M (2016) The rise of rural non-farm sector in Bangladesh: a distinct socio-economic transformation. AAFR 2(1):189-203

Back-of-the-Envelope Estimates of Next Quarter's Unemployment Rate. (2020). Available Online: https://www.stlouisfed.org/on-theeconomy $/ 2020 / \mathrm{march} /$ back-envelope-estimates-next-quartersunemployment-rate (accessed on 25 June 2020).

Barro RJ; Weng J (2020). The coronavirus and the Great Influenza Pandemic: lessons from the "Spanish Flu" for the coronavirus's potential effects on mortality and economic activity. NBER Work. Pap. Ser.Vol. 25.

COVID-19: (2020a). Putting people first. Available Online: https://www. unwto.org/tourism-covid-19 (accessed on 25 June 2020).

COVID-19: (2020b). Which workers face the highest unemployment risk? Available Online: https://www.stlouisfed.org/on-theeconomy $/ 2020 / \mathrm{march} /$ covid-19-workers-highest-unemploymentrisk (accessed on 25 June 2020).

COVID-19 and the St. Louis Fed: (2020). A note from President Bullard. Available Online: https://www.stlouisfed.org/covid-19 (accessed on 25 June 2020).

Dasgupta K, Murali S (2020) Pandemic containment and inequality in a developing economy. SSRN Electron J. https://doi.org/10.2139/ ssrn. 3604983

FSIN. Global Report on Food Crises; (2020).

Gerzon Mahler D; Lakner C; Castaneda Aguilar RA; Wu H (2020). The impact of COVID-19 (coronavirus) on global poverty: why subSaharan Africa might be the region hardest hit;Vol. 19.

Global Economic Prospects. (2020) Available Online: http:/pubdocs. worldbank.org/en/400631588785001198/Global-EconomicProspects-June-GDP-growth-data.xlsx (accessed on 25 June 2020).

Global Report on Food Crises. (2020). World Food Programme. Available Online: https://www.wfp.org/publications/2020-globalreport-food-crises\#: :text=The $\% 202020 \% 20$ edition $\% 20$ of $\%$ 20 The, to $\% 20$ their $\% 20$ perpetuation $\% 20$ or $\% 20$ deterioration. (accessed on 25 June 2020)

HLPE. (2020). Impact of COVID-19 on food security and nutrition (FSN)., No. March, 1-8.

ILO: (2020). As job losses escalate, nearly half of global workforce at risk of losing livelihoods. Available Online: https://www.ilo.org/global/ about-the-ilo/newsroom/news/WCMS_743036/lang\%2D\%2Den/ index.htm (accessed on 25 June 2020).

Inanc $H$ (2020). Breaking down the numbers: what does COVID-19 mean for youth unemployment? Mathematica.

International Tourist numbers could fall $60-80 \%$ in (2020a), UNWTO reports. Available Online: https://www.unwto.org/news/covid-19international-tourist-numbers-could-fall-60-80-in-2020 (accessed on 25 June 2020).

International Tourist Numbers Could Fall 60-80\% IN (2020b), Unwto Reports. Available Online: https://webunwto.s3.eu-west-1. amazonaws.com/s 3 fs-public/2020-05/200507\%20-\% 20Barometer\%20EN\%282\%29.pdf (accessed on 25 June 2020).

Kabanda J (2016). The effect of employment on poverty reduction in Rwanda: an empirical analysis, University of Rwanda (UR).

Messkoub M (2018) Population ageing and inter-generational relations in the MENA: what role for social policy? Popul Horizons 14(2):6172. https://doi.org/10.1515/pophzn-2017-0005

Monia G, Rim M (2018) The employment intensity of growth: evidence from Tunisia. J Econ Dev 43(3):85-117. https://doi.org/10.35866/ caujed.2018.43.3.004

OECD. (2020a). OECD Economic Outlook, Volume 2020 Issue 1. https://doi.org/10.1787/0d1d1e2e-en. 
OECD (2020b), Quarterly GDP (indicator). doi: https://doi.org/10.1787/ b86dlfc8-en (Accessed on 18 June 2020)

OECD (2020c), Unemployment rate forecast (indicator). doi: https://doi. org/10.1787/b487f2cf-en (Accessed on 25 June 2020).

Osmani SR (2003). Exploring the employment nexus: topics in employment and poverty., No. June.

Padovan D; Arrobbio O; Sciullo A; Gilcrease W; Gregg JS; Henfrey T; Wierling A; Schwanitz VJ; Labanca N; Dunlop T; Polo L; Candelise $\mathrm{C}$ (2019). Collective action initiatives. Some theoretical perspectives and a working definition., No. 837722, 2-68.

Possible fiscal policies for rare, unanticipated, and severe viral outbreaks. (2020). Available Online: https://research.stlouisfed.org/ publications/economic-synopses/2020/03/17/possible-fiscalpolicies-for-rare-unanticipated-and-severe-viral-outbreaks (accessed on 25 June 2020).

Rejeesh MR (2019) Interest point based face recognition using adaptive neuro fuzzy inference system. Multimed Tools Appl 78(16):2269122710

Sergio Correia; Stephan Luck; Emil Verner. (2020). Pandemics depress the economy, public health interventions do not: evidence from the $1918 \mathrm{flu}$; https://doi.org/10.2139/ssrn.3561560

Smith RD, Keogh-Brown MR, Barnett T, Tait J (2009) The economywide impact of pandemic influenza on the UK: a computable general equilibrium modelling experiment. BMJ 339(7733):1298. https:// doi.org/10.1136/bmj.b4571

Social distancing and contact-intensive occupations. (2020). Available Online: https://www.stlouisfed.org/on-the-economy/2020/march/ social-distancing-contact-intensive-occupations (accessed on 25 June 2020).

St-Denis X (2020). Sociodemographic determinants of occupational risks of exposure to COVID-19 in Canada, University of Toronto.

Sumner, A.; Hoy, C.; Ortiz-Juarez, E. (2020). Estimates of the impact of COVID-19 on global poverty. https://doi.org/10.35188/UNUWIDER/2020/800-9.
Sundararaj V (2016) An efficient threshold prediction scheme for wavelet based ECG signal noise reduction using variable step size firefly algorithm. Int J Intell Eng Syst 9(3):117-126

Sundararaj V, Rejeesh MR (2021) A detailed behavioral analysis on consumer and customer changing behavior with respect to social networking sites. J Retail Consum Serv 58:102190

Sundararaj V, Muthukumar S, Kumar RS (2018) An optimal cluster formation based energy efficient dynamic scheduling hybrid MAC protocol for heavy traffic load in wireless sensor networks. Comput Secur 77:277-288

Tiwari M, Tiwari T, Sam Santhose S, Mishra L, MR R and Sundararaj V, 2021. Corporate social responsibility and supply chain: a study for evaluating corporate hypocrisy with special focus on stakeholders. Int J Financ Econ

UN Women Headquarters. (2020). COVID-19 and ending violence against women and girls (EVAW COVID-19 briefs).

United Nations. (2020). The impact of COVID-19 on women (policy brief).

Vinu S (2019) Optimal task assignment in mobile cloud computing by queue based ant-bee algorithm. Wirel Pers Commun 104(1):173197

World Bank. (June 2020). Global Economic Prospects.

The World Bank predicts that remittances will experience the largest decline in recent history. (2020). Available online: https//www. worldbank.org/en/news/press-release/2020/04/22/world-bankpredicts-sharpest-decline-of-remittances-in-recent-history (access to 25 June).

Publisher's note Springer Nature remains neutral with regard to jurisdictional claims in published maps and institutional affiliations. 